Cahiers $d u$ MONDE RUSSE

\section{Cahiers du monde russe}

Russie - Empire russe - Union soviétique et États indépendants

$59 / 4 \mid 2018$

Varia

\title{
Adrian Brisku, Political Reform in the Ottoman and Russian Empires
}

A Comparative Approach

\section{Stefan Plaggenborg}

\section{(2) OpenEdition}

\section{Journals}

Electronic version

URL: https://journals.openedition.org/monderusse/10642

DOI: $10.4000 /$ monderusse. 10642

ISSN: $1777-5388$

\section{Publisher}

Éditions de l'EHESS

\section{Printed version}

Date of publication: 1 October 2018

Number of pages: 616-619

ISBN: 978-2-7132-2747-9

ISSN: $1252-6576$

Electronic reference

Stefan Plaggenborg, "Adrian Brisku, Political Reform in the Ottoman and Russian Empires", Cahiers du monde russe [Online], 59/4 | 2018, Online since 01 October 2018, connection on 06 January 2022. URL: http://journals.openedition.org/monderusse/10642 ; DOI: https://doi.org/10.4000/monderusse.10642 


\section{Adrian BRISKU}

\section{Political Reform in the Ottoman and Russian Empires A Comparative Approach}

London - New York : Bloomsbury Academic, 2017, 288 pages.

Studies conducted in comparative history have focused on the Ottoman and Russian Empires mainly in the context of the history of empires; however, they have hardly examined them in relation to one another. While access to sources and literature requires scholars to be proficient in the relevant languages, the comparative approach poses a challenge in itself. Comparative history is an intellectual operation structuring and organizing history in a way that is not inherent in history as a sequence of events. Hence, comparative history must not only carefully explain why something has to be compared and what is being defined as the tertium comparationis, but also what exactly the reader can understand better with the aid of such a comparison rather than without it.

It is thus recommended to read Brisku's book from this perspective. Its subject matter is about two empires of the $19^{\text {th }}$ century, whose relations - for the most part - were characterized by mutual hostility. The significance they both bore in the concert of powers was highly variable. Temporarily, Russia even acted as protector of the Ottoman Empire after 1833. As far as the dynasty, the role of the aristocracy and the economic development were concerned, they had hardly anything in common. Brisku, therefore, made a wise decision when he chose not to concern himself with a comprehensive comparative history of both empires but to focus on only one aspect. He analyzes the language of reform and narrows his focus even further by concentrating on the language of the political protagonists in Istanbul (mainly Reshid und Midhat Pashas) and St. Petersburg (Michael Speransky and Nikolai Miliutin). The names already hint at the chronological dichotomy of the book. The first part covers the first half of the $19^{\text {th }}$ century, whereas the second half starts with the Crimean War and concludes - in the case of the Ottoman Empire with the constitution of 1876, and with the so-called constitution of Loris-Melikov of 1881 in the case of Russia. Yet the Russian and Ottoman Empires are not depicted and interpreted in joint chapters, but rather in separate ones in which each topic is discussed in parallel.

Brisku is of the opinion that "the vocabularies could undermine the very power" of both dynasties (p. 2). The alternative to the prevailing autocratic system was, as Brisku puts it, reflected in the language of political reform. Reform in Brisku's words means "conservative reform", i.e. the tension between the modernization and stabilization of the prevailing system, especially on the international stage. Following modernization theory, which Brisku's approach is explicitly opposed to, Hans-Ulrich Wehler's term of the "defensive modernization" reflects more precisely what is meant here. Behind the language of reform hides a somehow "Wortmanian" approach as the book itself is about variants of legal consciousness, i.e. notions of law and new institutions, the purpose of which was to stabilize the monarchy and the significance of each Empire with regard to foreign affairs. 
Brisku's approach encompasses four chapters. Initially, the reader can expect an account of Speransky's ideas of "true monarchy" and of how the issue of the monarch's unlimited power can be conciliated with the existence of permanent laws. The role of the religion is exemplified by describing the "Grand Design" of Czar Alexander I, a draft of a post-Napoleonic European peace order based on Christianity. Both failed as is generally known, while the concept for the law itself did not disappear at all, although Alexander's missionary vision was offishly rejected by the British.

The firman hatt-l şerîf of 1839 (permanently referred to as hatt-ı hümâyûn in the book, as is the case with the firman of 1856) constitutes the key document of the Europeanizing, modernizing and centralizing reform period of the tânzîmât. For the first time the Sultan's subjects were granted legal rights irrespective of their religious affiliations. For the reformer Reshid Pasha it was all about aligning the developments encountered in the Ottoman Empire with those in Europe. Its ties with Britain were supposed to support this endeavor. In contrast to the Russian Empire, however, religion was to play a less important role. Legal reform was the consequence, and Europe served as a prime example for Reshid Pasha.

The second part, which is also made up of two parallel chapters, deals with the results of the Crimean War. Once again Brisku highlights its importance as a motive for reform and describes concepts, characters and factions involved in the emancipation of the serfs in great detail before turning his attention towards his protagonist Nikolai Miliutin and the zemstvo-reform. Roughly summarized, the line of thought pursued by Brisku is as follows: it sets out with the formation of the afore-mentioned institutions of local self-government and the elections that came with it, before concluding with the idea of a zemstvo-parliamentarianism. The latter failed before Loris-Melikov even began working on the scheme of a "constitution" during the crisis at the beginning of the 1880s; the shortcomings of this "constitution" with regard to civil liberties and the limitations of monarchical power are pointed out by Brisku.

In comparison to Russia, the Ottoman Empire - facing opposition from the conservatives and being under difficult internal as well as external conditions to be sure - was able to advance at a much faster pace when establishing its constitution of 1876, the "father" of which was Midhat Pasha. Brisku refers to the continuities and also to the great breaks with regard to the rule of law and the finally emerging constitutionalism, which was on no account inevitable. When crises started to accumulate during the 1870 s, a decade characterized by a multitude of catastrophes for the Ottoman Empire, it was Midhat Pasha who was able to push the idea of constitutionalism, not least because of his experience as provincial governor. This idea was not something he was born with; it was rather the emerging public sphere and some intellectuals (parts of the intelligentsia) who paved the way which the government finally decided to take.

Brisku opens the door further when it comes to comparing the Ottoman and Russian Empires. It goes without saying that such a book can only be the beginning. In the course of four chapters and with the help of two chronological 
cross-sections the author succeeds in making the issue of reform and stabilization comprehensible by focusing on the selected protagonists. The law and the new institutions, according to Brisku's findings, were to stabilize the political structure of the empire and to ensure or rather improve its status with regard to foreign policy; a development which eventually led to constitutionalism.

However, the author pays dearly for this narrow thematic perspective. What is missing is an integrative examination since the topic is by no means specific to these two empires in the $19^{\text {th }}$ century. The role of the law in relation to the unlimited power of the monarch has been a perennial issue at all times and in almost every consideration as far as theories of the state were concerned, even outside of Europe. Constitutionalism is what makes the difference. But it seems to be the wrong term in this case. Basically, it was a matter of impeding the constitution with the aid of the law because Russia in particular did not take on this political slogan of the European revolution of 1848, a point which Brisku does not mention at all. The Ottoman Empire did but it was pressed to do so from outside and from within. Thus, what do we learn? The notion that people who considered the idea of a "defensive modernization" existed in both the Russian and Ottoman Empires is nothing new.

The problem with this kind of comparative history in parallel chapters is the fact that neither the expert of Russian history nor the one specializing in the history of the Ottoman Empire will be truly surprised. This is due to the aspiration of the book. Comparative history should first of all justify why, out of a set of options, a certain issue has been selected before defining the analytical points of reference in the shape of the tertium comparationis.

Dependence on mostly secondary literature runs the risk of merely reproducing research. The author is more familiar with the Russian than with the Ottoman Empire. Thus he misses out on some central aspects. The most important aspect of decentralized institutions of power in the Ottoman Empire, the local notables, is missing entirely; without it, it is hardly possible to fully understand the sense behind the centralizing and state-building reforms of law and administration. The role of the millet-system should also be discussed in the context of the language of reform as it allowed non-Muslim ethnic groups such as Greeks, Armenians and Jews to have limited cultural autonomy, which was countermanded, however, by the reform plans and the constitution that were first and foremost designed to expand the state. The bilingual approach to this topic takes its toll at this point as it is based on English secondary literature and some Russian literature but it does not capitalize on the abundant material made available by French researchers on the subject of the Ottoman Empire in the $19^{\text {th }}$ century. Furthermore, it disregards Turkish historiography and does not consult the original Ottoman sources. (The continuous use of the acronym hatti to refer to the firman of 1839 must be changed to hatt for the sake of being grammatically correct). This is particularly painful because - of all things - Brisku especially emphasizes (the importance of) language. It is therefore inevitable to pay close attention towards historical semantics not only with regards to the terms of reform but also when it comes to 
making use of the terms found in those sources as their contemporary usage may reveal major differences as far as law and political order are concerned.

Brisku's book has offered a fine description of the topic. Notwithstanding its merits, comparative history has still a lot to do.

Stefan Plaggenborg

Ruhr-Universität Bochum 